\title{
EDUARDO RIBEIRO AVENUE: Rescuing the past as a guide for the tourism in the city of Manaus-AM
}

\author{
Yara Araújo Magabia \\ Márcia Raquel Cavalcante Guimarães ${ }^{b}$ \\ Luciane da Silva Querogac
}

\begin{abstract}
This study examines the historical, socio-cultural and tourist elements that are part of the composition of Eduardo Ribeiro Avenue, located in the city of Manaus-AM. Having as its general objective: to investigate how the Eduardo Ribeiro Avenue and the historical and tourist aspects that compose it, can be analysed in the context of heritage interpretation. Being its specific objectives: to identify the history of this avenue and its importance to the formation of cultural manauara's patrimony, raise the current elements that complete the landscape of the street and analyse its relationship with tourism and, suggests a touristic visitation route focused specifically for the Eduardo Ribeiro Avenue having as foundation the principles of patrimonial interpretation. A qualitative research with descriptive and exploratory objectives using bibliographical, documental and field technical procedures. Concerning the results, the Eduardo Ribeiro Avenue is considered the main artery of the centre of Manaus, this street has throughout its extension important historical buildings in addition to being one of the centres of commerce in the capital. The historicity is embodied in its urban layout, in its paving, in its cobblestones, in the century-old buildings that make it up along with its infrastructure, making the Avenue a very relevant space for tourist activity in the capital. Its relationship with tourism is based on the perspective of the rescue of a historical legacy for the manauara society and most importantly, the possibility of scripting the aforementioned avenue by the local tourist trade having as a foundation the principles of patrimonial interpretation.
\end{abstract}

\section{Keywords:}

Patrimonial Interpretation

Tourism

Avenue Eduardo Ribeiro

Tourist itinerary 


\section{INTRODUCTION}

Tourist activity can become an important instrument in valuing and preserving the historical and cultural heritage of a locality if developed with respect for local customs and by involving the population in its practices. The interest in knowing the architecture, the cultural manifestations, the traditions and the way of living of other people, demonstrated by the tourists have been an agent of consciousness-raising with the local community, for Beni (p.92, 2007,) "tourism stimulates countries to protect their civilizations and cultural inheritances".

To provide context for the object of study in advance, the origin of Eduardo Ribeiro avenuewas born, according to the historian Mansour (2017), from Governor Eduardo Ribeiro's desire to modernize Manaus and transform it into the "Paris of the tropics". During Eduardo Ribeiro's government, the capital of Amazonas went through various transformations, one of which was the construction of the avenue that bears his name. Eduardo Ribeiro Avenue is home to several important historical buildings along its length (the Amazon Theater, the Nossa Senhora da Conceição church and the Palace of Justice, for example), as well as being part of the commercial centre of Manaus and representing one of the most visited tourist spots in the state, although this was not always the case. Considering the identification of the socio-historical elements of the Eduardo Ribeiro Avenue and its relation with the tourist activity, the research of the Eduardo Ribeiro Avenue was sought under the viewpoint of patrimonial interpretation, as it is believed that the set of tools and techniques used in the patrimonial interpretation approach can contribute to a better understanding of the meaning and relevance of such a street and its buildings for the visitors who come to the capital as well as for the population living there.

The proposed study, through its objectives and questions, is relevant for its investigative aspect about the history of one of the most important streets of the city, which, consequently, unveils relevant facts about the history of the capital of Amazonas itself. At the same time it brings a proposal for a tourist route that seeks to demonstrate the Avenue within a different context, using tools that provide a new look at this place. Finding, in parallel,the relationship of Eduardo Ribeiro Avenue and the elements that compose it with the tourist activity in Manaus assisting in the local tourism planning. In summary, the justification for this research is substantiated by addressing questions related to the historical value and conservation of the memory of a landmark, arousing feelings of belonging and appreciation of cultural heritage in residents and visitors through the proposal of an itinerary as an interpretive strategy, favouring the tourist promotion of Manaus as destination. Furthermore, a society that desires to work the tourist activity in such a way that it becomes an instrument to value its traditions must know and embraceits history. Other factor that proved relevant to the realization of this research was the absence of a script specifically focused on the socio-cultural history of Eduardo Ribeiro Avenue.

As to Methodological procedures, the qualitative approach, the descriptive and exploratory nature of the objectives of this study, the chosen technical procedures (bibliographical, documental and field research), the data collection instruments (fiches and summaries) and the analysis of these data are explained. As to structure, this article is composed of topics and subtopics, starting with the introductory aspects, followed by the theoretical contributions, composed of the researchers who based the entire study, further on we have the methodology with all the steps that guided the research, the results that bring a synthetic analysis of the data raised and lastly, the final considerations summarizing the entire subject discussed, bringing scientific and marketing contributions about the theme addressed.

\section{Theoretical Foundation}

\section{The relevance of cultural-historical heritage for the formation of local identity and its relation- ship with tourism}

The act of travelling can be a vector of positive influence on the cultural formation of society, mainly by providing the experience of getting to know a city, involving stories and remarkable elements about its culture and characteristic environments. In this context, "the existing cultural heritage is one of the elements of great attraction for tourists, as well as for the memory and ethnicity of the society constituted in these spaces" (GUIMARÃES, MAIA, OLIVEIRA E TRICÁRICO, p.484, 2020).

According to Lohmann and Netto (p.431, 2008), the word has its origin in the Latin patrimonium (pater = father and monium = recognized value) and refers to the assets left by parents to their children or the inheritance left by a person to his direct descendants. Barretto (p.110, 2007) explains that the word patrimony "applies to the set of assets that some person or institution owns and therefore one can speak of public patrimony, private patrimony or national patrimony." It is valid to quote Choay (2001) when the author clarifies what it means to society:

The patrimony is the legacy we receive from the past, live on in the present and pass on to future generations. Our cultural and natural heritage is an 
irreplaceable source of life and inspiration, our touchstone, our reference point, our identity. (p.11, 2001). Therefore, the patrimony walks side by side in the process of cultural valorization that occurs from the moment there is a greater appropriation of the local history by the society, where the historical trajectory of the locality should be highlighted to avoid cultural losses, and mainly, provide a new look under the perspective that the history that constitutes the place is unique, being culturally significant and able to generate a bridge between the past and the present (OLIVEIRA; GUIMARÃES; PRATA \& SILVA, 2019). Pupo (2011) states that patrimony is synonymous with the investigation, registration and interpretation of material and immaterial objects, such as historic centres, sets of monuments, buildings, their movable belongings and works of art, traditions, music, festivals and the landscape that compose them.

There is a consensus among several studies of the tourism phenomenon about the primary role of cultural resources in the composition of the tourism offer, as most tourists travel in search of something new, of people with habits different from their own and of experiences that can only be lived by entering totally unknown cultures. This pursuit of tourists for different cultures is emphasised by the words of Aranha and Guerra (p.133, 2014), "to make tourism is to travel for pleasure out of one's usual surroundings, and arises from the desire to know values and customs of other peoples. This leads to a flow of people coming and going, seeking to enjoy the special qualities and peculiar characteristics of the places."

The special and peculiar qualities and characteristics of the places are, fundamentally, the unique nature existing in the place and the culture of the people who inhabit it, this culture is composed of elements that allow them to self-affirm their own cultural identities. This identity, in turn, is, according to Hall (2001), dialectically formed between the individual and the society in which he lives, the author also states that the process of identity construction includes self-identification and identification recognized by others, thus being changeable. Identity is the factor that differentiates one people from another and, in cultural tourism, is one of the reasons that drive the movement of people. Therefore, an avenue with several historical buildings can also be considered a place where the culture and identity of a group of people are originated and manifested, so it is necessary that its historical and cultural aspects are valued and preserved.

Given the above, it is understood that the relationship of interdependence existing between the tourism phenomenon and patrimony preservation can be beneficial both for the development of tourism and for the enhancement and maintenance of historical and cultural assets of a particular social group.

\section{Space and landscape: a geographical approach to the elements of an avenue and its touristic poten- tial}

Geography and Tourism are closely related to each other, because the tourism phenomenon needs geography to be understood, in turn, the geographic science appropriated tourism as an object of study to become more comprehensive. Its contributions to the understanding of the tourism phenomenon, as emphasized by Xavier (2007), are:

The role of geography in the quality of educational systems in tourism is of great importance. This is justified by the treatment given to spatial relations and by considering environmental, social, cultural and ecological aspects, besides offering subsidies for the treatment of the three sustainability of tourism: ecological, social and economic. (p.28, 2007).

With the expansion of the territorial limits of cities came the great avenues, which are wider than streets, designed to accommodate the growing flow of people and the most diverse means of transport (carriages, carts, cars, bicycles, among others) that, like the cities, underwent significant transformations and directly influenced the evolution of the avenues. Avenues and streets are the veins and arteries that carry life within cities and make room for cities to grow. It is in them that the social life of the city truly happens, since they house residences, historic buildings, shopping centres, hospitals, squares, parks, bus stops, among other buildings of great importance for the functioning of society, in addition, it is through the avenues and streets that people transit every day, moving from home to their workplace, for instance. They are an integral part of the landscape and space, which in the view of Santos (1988) is the result of the sum and synthesis, always remade, of the landscape with society through spatiality, where the landscape has permanence and spatiality is a moment. He complements this by stating that society is subordinated to the law of the pre-existing space, not being subordinated to the landscape, which, taken in isolation, is a passive vector and a value attributed to each fraction by life that metamorphoses the landscape into space, which allows the selectivity of spatialization.

For Guimarães and Pereira (2012), tourism appropriates this interaction between man and landscape at the time it plans and organizes the tourist attractions that will be available to the resident and the visitor/ tourist to know, interpret and experience the products materialized in the urban landscape, such as buildings, squares, streets and monuments. The same authors clarify that the landscape considered as a form of the geographical space expresses movement, 
historicity presenting itself as a reproduction of history continuously, where past and current active elements, materialize the relations of society at a particular time in human history. Therefore, the tourist activity is characterized as a phenomenon, essentially, sociocultural, based on the displacement of people by the geographical space, where the avenues and its integral elements (space and built landscape) are elements that can be better used as inputs of tourist attraction.

Space and Landscape are the raw materials of tourism, without the physical and social elements that make up the set of this binomial, the tourism phenomenon, probably, would not exist. This combination contains the aspects that attract visitors to places around the world, on the other hand, these tourists and residents are fundamental to the consumption of this landscape, since the human being and his view of what he observes are the factors that give life to these concepts. Thinking of the landscape as the primary product of tourism activity is a thought that finds support in the statement of Beni (p.177, 2007): "in short, the supply in tourism can be conceived as the set of natural and cultural resources that, in essence, constitute the raw material of tourism activity because, in fact, it is these resources that cause the influx of tourists". Vieira and Oliveira corroborate with this understanding by saying that:

The beauties and exotic scenarios promoted by tourism publicity and loaded with symbolic content, permeate the human imagination, induce the desire for travel and subsequently create the necessary motivation for the dislocation of the tourist to occur. (p.10, 2012).

Natural and artificial aspects of the territories become tourist attractions when people attach meanings to them or when these elements are only found in a certain place, this exclusivity or landscape peculiarity, expresses, in a way, the identity of a place. Understanding this relationship it is possible to see that the elements that make up a great avenue, such as Eduardo Ribeiro, only gain meaning through interaction with society. For this reason it is so important that the inhabitants of a city, like Manaus, know the spaces that compose it and see themselves in these places. One way to provide residents of a particular location with greater knowledge about its composition and history, is to insert them in the development of the tourist activity in the place. Creating a new product like a tourist itinerary, for example, bringing the community into the process and using methods that further enrich the tourist experience, is a great way to both enhance the historical, cultural and social riches of a place, and boost tourism activity there.

\section{Formatting tourist routes according to the logic of heritage interpretation}

There are many ways to get to know a city and its history, each person has their preferences when it comes to going out on the streets in search of getting acquainted with the elements of an unknown place, and many tourist attractions are provided to meet such preferences. The development of interpretative activities in patrimonial siteshas grown with the use of communication and information technologies in search of promoting the places, while enhancing and enriching the visitation (GUIMARÃES, MAIA,OLIVEIRA e TRICÁRI$C O, 2020)$. Thus, the same authors state that the heritage value of a cultural element is aided by the dissemination of public communication, as part of a broader conservation process, involving the dissemination, disclosure, presentation andinterpretation of the patrimony.

Interpreting consists in receiving information and understanding it to pass it on, so it is necessary that the techniques and tools used in patrimony interpretation are enlightening and easily accessible (CARDOZO, 2012). Among other aspects, the patrimony interpretation has as its primary function to be a means of transmission of information about the heritage visited, in addition to enabling the enrichment of the lived experience, facilitating access to facts and striking aspects of the history of a place(GUIMARÃES, MAIA, OLIVEIRA E TRICÁRICO, 2020).

From the perspective of patrimony interpretation, the elements that are part of an itinerary can be better understood and, consequently, used for the practice of tourism activity, for example. Among the several ways to unveil a locality are the tourist itineraries, defined by Bahl (p.42, 2004) as the "detailed description of a trip or its itinerary. Still, indication of a sequence of existing attractions in a locality and worthy ofbeing visited". Whereas Boullón (p.209, 2002) defines that the "routes are the circulation routes selected by the tourist traffic of vehicles and pedestrians, in their displacement to visit the tourist attractions and to enter or leave the tourist attractions and to enter or leave the city". These routes or paths are formatted in accordance with the interest of tourists, for example, if a group of visitors shows preference for museums and historical buildings, the appropriate route for them would include the streets of the historic centre of a city. Complementarily, Murta and Albano (2002) indicate that the itineraries are broader routes, punctuated by attractions and services. along the way and can be performed by bicycle, horse, car, boat and also on foot. The common point among the definitions cited seems to be the existence of tourist attractions of great historical and/or cultural value throughout the extension of these itineraries. 
Based on Bahl (2004) for developing itineraries, the following aspects should be taken into consideration: Objectives/Direction/Title/Attractions, Days and Times/ Locations for shopping/meals/fees, Duration/Times/ Location (departure/arrival), Programme (product)/ Testing/Price, Dates of departure (frequency)/ Operatingexpenses, Dissemination/ Marketing/ Evaluation, Driver/ Guide/ Animation, Itinerary/Number of stops/ Transportation. (p.96, 2004).

According to Boullón (2002), an itinerary can be important for two reasons: 1) for the points or places it joins and, 2) for itself. That is, an itinerary can be a tool to enhance the tourist experience for being the path that unites important tourist landmarks or for the attractions that it has in its extension. In addition, elaborating a tourist itinerary focused specifically on a certain place can, according to Guimarães (p.233, 2012) "work as a development strategy of the tourist destination and inclusion of the societies within a process of constant interaction".

Building a tourist itinerary focused specifically on a relevant place such as Avenida Eduardo Ribeiro enables the valuation of the patrimony existing in it. Combining this route to the techniques of heritage interpretation makes this product even more diversified and attractive both from the point of view of conservation of the historical and cultural assets existing there and for the quality of the tourist experience in this locality. In order for the combination itinerary/ patrimonial interpretation to achievethe status of a tool for valuing the heritage and encouraging the development oftourism, it is necessary that it be developed with respect for the physical and social characteristics of a locality. characteristics of a locality as well as including the population in the whole process.

\section{METHODOLOGICAL PROCESS}

Based on Dencker (1998), for the accomplishment of this study, the research objectives were exploratorydescriptive of qualitative nature, since the need to investigate in depth and understand the complex social phenomena in the context of Eduardo Ribeiroavenue which allowed to embrace the multiple elements responsible for its configuration, improving ideas or discovering intuitions, identifying the factors that contribute to the occurrence of these phenomena through the observation of facts (DENCKER, 1998). Very peculiar factors such as the relevance of the historical and cultural elements that make up the Eduardo Ribeiro Avenue for the formation of manauara cultural patrimony, its relationship with the touristic activity, in addition to the identification of the current components that inte- grate the road.

It is worth noting that this study was based on the correlation between cultural patrimony, interpretation and tourism, highlighting the possibilities of integration between both, through the rescue of the historicity of a street corner combined with the proposed tourist itinerary for use of visitors and residents, which may be measured in the future as to the aspect of new experiences, tourist consumption and interpretative possibilities of this street corner. It was used, essentially, documentary sources as well as bibliographic, iconographic, cartographic surveys and field researchto compose the analysis. The data collection instruments were summaries of the researched publications and documents, and also of the observations and records made in the field. The information obtained in loco were observed and catalogued along with the photographic records that were obtained through visits made to Eduardo Ribeiro Avenue during the field and documentary research.

The analysis of this material was processed in the treatment and qualitative verification of the data collected during the research, based on the confrontation of the theoretical review with the reflections made by researchers after reading the bibliographic and documentary materials and the observations made during the in loco visits carried out during the field study.

\section{RESULTS AND DISCUSSION}

\section{From water to concrete: the formation of the ma- nauara socio-cultural identity in the context of Edu- ardo Ribeiro Avenue}

It was during the expansion of the rubber cycle that Manaus became one of the most important cities of the newly proclaimed Brazilian Republic, the large amount of resources from the latex trade enabled the numerous actions that were undertaken. To become a modern and "civilised" city, the process of constructing grandiose public buildings, squares, bridges, a modern port, streets and avenues, the installation of public transport services, electricity, water supply and sewage, as well as the creation of new laws and decrees that changed the lives of the city's inhabitants forever. The legacy left by the rubber cycle to Manaus can still be observed today, portrayed in sumptuous buildings, squares and streets that are currently part, in its great majority, of the Historic Centre of the city, and in the customs of the population that, in turn, were greatly influenced by the large contingent of immigrants from the North-east that arrived in the city during the period and by the drastic changes that occurred in the physical 
structure of the city, in addition to the codes of conduct that also exerted strong influence on local sociocultural construction.

In this context is that Eduardo Ribeiro Avenue emerges during the opulent rubber cycle (MESQUITA, 2019). The reports of Mesquita (2005; 2019) and Souza (2005) point out that from the end of the eighteenth century and throughout the nineteenth century a large number of travelers and pathfinders visited the Amazon territo$r y$, and Manaus was one of the places that most received them, we highlight the trips of Robert Christian Avé- Lallement, Henry Lister Maw, Alfred Wallace, Henry Bates and the Swiss couple Jean Louis and Elizabeth Agassiz, among others, the historical accounts of these travelers report a unique feature of Manaus: it was cut by numerous streams, known in the region as igarapés ${ }^{1}$, which, in turn, were widely used by the population both for recreation and work activities and for mobility. Batista (p.171, 2013), points out that the population of Manaus in the year 1852, was concentrated amid a dense water network, "with the Manaus stream to the east, as the limit of the urban core; and to the west the Cachoeira Grande stream, in the São Raimundo watershed, was the limit".

However, only the large amounts of money coming from rubber without proper administration were not able to change the features of the municipality, it was necessary that a young and determined politician, nurtured by modern ideas and strongly influenced by European models of urbanization, rose to the post of governor of Amazonas (MESQUITA, 2019). That person was Eduardo Gonçalves Ribeiro, who undertook one of the most prosperous governments in the history of the State, from 1892 to 1896 , the same established a project of modernization and beautification of Manaus that, in partnership with the English, executed several urban infrastructure works, "necessary for the welfare of the local population and, indispensable for the adequate ambience to the resident foreigners", reinforces Batista (p.173, 2013). The Expansion and Improvement Plan devised by Eduardo Ribeiro sought to adapt Manaus to its new functions of world rubber capital, Dias (2007), clarifies on this issue that:

Modernising, beautifying and adapting Manaus to the economic and social demands of the time became the main objective of the local administrators. It was necessary that the city presented itself modern, clean and attractive to those who visited on business or intended to settle permanently. (p.28, 2007).

Thus, one of the first measures taken by the new governor was to enact, in 1892, Law no. 12 of 01/10/1892, which authorized the government to order the filling of

${ }^{1}$ Small stream or river arm that usually connects two islands. They are very common in the Amazon biome. several igarapés, since the Department of Hygiene and Health pointed out as urgent measures their filling, as reiterated by Mesquita (2019), Dias (2007) and Batista (2013). Among the streams that should be embanked was the one of Espírito Santo, or what was left of it, since, as seen previously, part of this watercourse had already been embanked, between the 1940s and 1960s, the area that was still taken by the waters of the igarapé occupied a prominent space in the city beautification plan, planned by Eduardo Ribeiro, since the extension of the then Comendador Clementino street, referenced at the time as Palace' avenue and currently Eduardo Ribeiro avenue, according to Mesquita (2019), depended on this work. This governor planned to transform the space into a beautiful and monumental avenue that would be an example of the great European roads in the middle of the Amazon forest, such as the famous Champs- Élysées in Paris.

Law 36, of 29 July 1893, and what remained of the igarapé do Espírito Santo began to be filled in (MESQUITA, 2019).

Figure 1 - Drainage of the Espirito Santo creek (left) and galleries built before paving near the $\mathrm{Ma}$ naus Port area (right) between the years 18921900

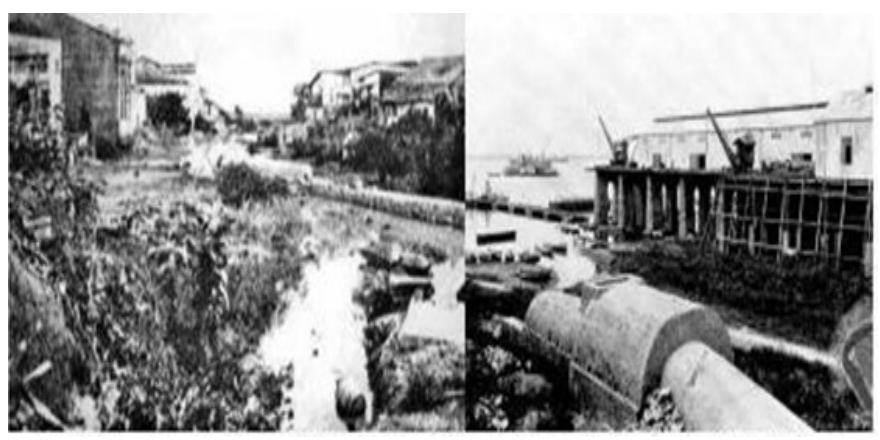

Source: <http://manausdeantigamente.com.br>

Eduardo Ribeiro avenue (Figure 2 and 3), represented the greatest symbol of modern and rich Manaus that was sought to show, according Andrade (1984), Monteiro (1998) and Mesquita (2019), this road, like many streets and avenues of the capital, was originally covered with cobblestones of gray granite, imported for the weight of gold from Portugal, its pavements were covered with large slabs of marble, which gave a picturesque appearance to the city, thus recalling the old neighborhoods of Lisbon, it was wooded with Ficusbenjamins, trees that filled the streets forming real green necklaces, it was lit by arc lamps showing the electric lighting still new in the rest of Brazil. 
Figure 2 - Eduardo Ribeiro Avenue in 1896 (in building)

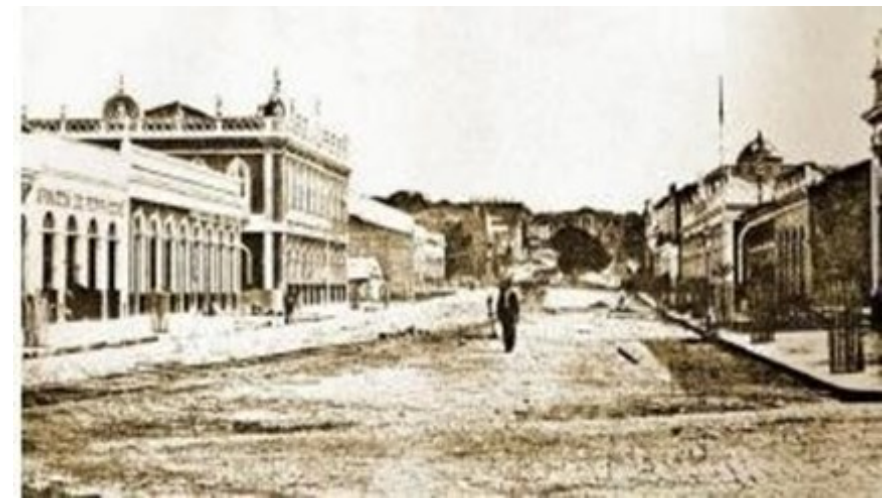

Source: Anjos \& Pereira (2011)

Figure 3 - Eduardo Ribeiro Avenue in 1900

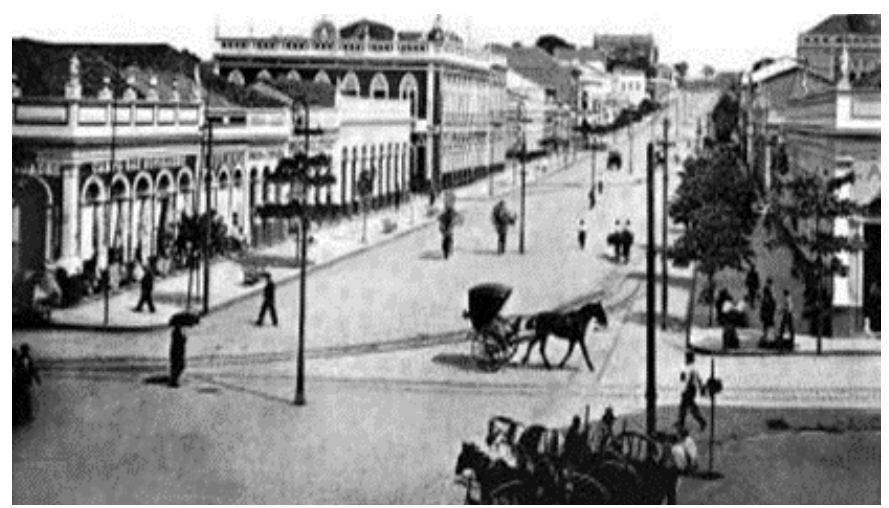

Source: Anjos \& Pereira (2011)

In its extension several buildings, among them the most elegant warehouses of fashion, exhibition and sale of objects of art, fashion designers and tailors ateliers, hotels, restaurants, pharmacies, bars, grocery stores in addition to the impressive Amazonas theatre, the Palace of Justice and the Cathedral of N. S. Conceição. S. da Conceição, which majestically complemented the architectural set of the Avenue and materialized the glamour of the Belle Époque manauara, ratify Garcia (2014), Mesquita (2019) and Andrade (1984).

Between the years 2015 and 2016 the Avenue was the target of revitalization works (Figure 04), according to the electronic portal of the Manaus City Hall the project of the new Eduardo Ribeiro was executed by the municipal secretary of infrastructure (Semif) after approval of the Institute of Historical and Artistic Heritage (Iphan). The goal was to bring back the original aspects that the way presented at the time of its construction, where it was not found the original pavement was performed a work with pigmented concrete blocks and quartzite stones

Figure 4 - Revitalization works on Avenida Eduardo Ribeiro (section of the intersection with Rua 10 de Julho) between 2015-2016

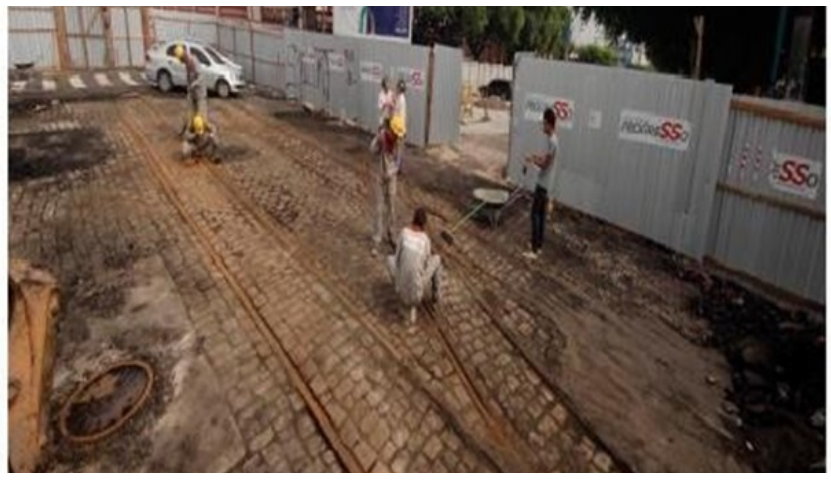

Source: <http://manaus.am.gov.br>

For Mesquita (2019) in the last three decades of the twentieth century, the Avenue was losing its relevance to other avenues of larger dimensions and that presented a more intense trade, yet it still preserves its function as a commercial avenue quite relevant to $\mathrm{Ma}-$ naus, especially to the centre of the capital. It is considered an important area for tourism activity for housing several historical buildings representative of the evolution of Manaus, many of them housing cultural spaces and/or museums and already under legal protection (in the three levels - Municipal, State and Federal), as well as for integrating the Historic Centre of the city, area listed in the Municipal and Federal levels.

The interesting thing to note is that on Sunday mornings the car traffic is prohibited in part of the way, this area is held the traditional Craft Fair Eduardo Ribeiro, this weekly event happens to twenty years and attracts many residents and tourists, who usually take the typical breakfast of the region in the stalls set up there, and can appreciate and buy a wide variety of handicraft products. In this sense, the configuration of the landscape of this place followed the past and current needs of the capital manauara, in a symbiosis between old and new, becoming a lived space of cultural, commercial and tourist consumption, but above all, manifestation of identity and appropriation by the local society.

\section{Past and present: the built landscape as a tourist attraction in Eduardo Ribeiro Avenue}

The urban space occupied by Eduardo Ribeiro avenue presents a considerable number of cultural resources that can be considered tourist attractions and are materialized in symbolic buildings of different periods of the history of the capital of Amazonas as well 
as the socio-cultural transformations of the manauara society. Despite the numerous transformations that the Avenue has undergone, a good part of its architectural ensemble still resists time and real estate pressures, this set of historical buildings along with the characteristics of the road itself (its paving, its layout, its paving, its location and the history of its construction) are configured in an important tourist resource for the city, because, "tourism and consumption activities are important elements in the promotion and dissemination of all major cities", as stated by Hayllar, Griffin, Edwards and Aldrigi (p. 46, 2011).

Eduardo Ribeiro avenue is a centennial avenue, whose conception dates back to the year 1892 and conclusion in the year 1902, located in the city centre and is considered short, with little more than one kilometre in length, beginning at the Obelisk (monument to the first centennial of the elevation of the Vila da Barra do Rio Negro to the category of city), in front of the gardens and the Matriz Church, and ends at the Antônio Bittencourt Square (Congress Square). Its route begins with a central border where the Obelisk and the Municipal Clock are installed, on the left side is the Cathedral of N. S. da Conceição (Matriz) as well as its gardens and the 15 de Novembro Square (Matriz). On the right side, on the corner with Marquês de Santa Cruz street, is the Receita Federal building ${ }^{2}$, the Post Office ${ }^{3}$ building is on the corner with Theodoreto Souto street, next to this building is part of the historical houses of the avenue and some commercial buildings. Following its course, there is an intersection with Sete de Setembro Avenue, on the corner with the Matriz Church. Further ahead it is in parallel with Henrique Martins Street, Saldanha Marinho Street and 24 de Maio Street.

On the block bounded by the streets José Clemente and 10 de Julho, on the right side are the São Sebastião square, a Tourist Assistance Centre (CAT) and the Amazonas theatre, on the left side, at the corner with the street José Clemente is a branch of the Caixa Econômica Federal, the building of the old Court of Justice, today the Palace of Justice Cultural Centre and on the corner with the street 10 de Julho there is an area in which you can see part of the original rails where the electric trams used to circulate and an information board with the itinerary that they followed. Further up, between 10 de Julho and Monsenhor Coutinho streets, specifically on the right side, abandoned historical buildings can be seen as well as hotels and a residential building. On the left side, the traditional Ideal Clube building stands out. The Avenue ends when it meets the Antônio Bittencourt square at the intersection with Monsenhor Coutinho street, originally the road reached the confluence with Ramos Ferreira street, where today is the building of the Amazonas ${ }^{2}$ Currently used as the provisional headquarters of the Institute for National Historical and Artistic Heritage - Iphan ${ }^{3}$ It is closed
Education Institute - AEI (the Government Palace would be built in this place, but the work was never fully completed) for this reason this building must also be considered when discussing the configuration of the landscape of Eduardo Ribeiro avenue.

After the revitalization process (which took place between the years 2015 and 2016) the Avenue began to present some of its original aspects again, today the paving on the roadway is composed of precast concrete pieces embedded, on the pavements were deployed São Tomé type stones similar to the original paving and at the curb cobblestones were restored, in addition, at some points the lighting is decorative and the poles are the Cajado de São José type. Today, traffic on the street is heavy and follows the direction centre-district on the extension of the intersection with Sete de Setembro avenue up to Monsenhor Coutinho street. Below the confluence with Sete de Setembro avenue until reaching Marquês de Santa Cruz street traffic follows the direction neighbourhood-centre.

The identification of the current and historical aspects of the Avenue, as well as the verification of the existing structural problems in it, are very important both for the preservation of the street and its components, and for the better development of the tourist activity in the place, since "in the same way that a magnificent tree loses its aesthetic value if it is surrounded by a garbage dump; a building, a church or a monument diminishes its beauty if the space that surrounds it is not harmonized with its architecture and its scale", as emphasized by Boullón (p.252, 2002). All these interventions in the avenue since its construction, led these researchers to adopt a comparative tool of the landscape through images of some spaces of the avenue in its original form with the current scenario of them. This exercise focuses on clarifying how the interventions undertaken in the street uncharacterized it and how the contemporary aspects of the avenue would interfere with the visual configuration of the landscape, elements that reinforce the uniqueness of the avenue and help to be considered one of the most important streets of the Historic Center of Manaus, both for local trade and for tourism activity.

For this analysis were chosen the places that present greater contrast between its original and current landscape, whose previous scenario was much more appreciated by the manauara population, the defined spaces are: 1) Corner with Monsenhor Coutinho Street; 2) Space between the streets 24 de Maio and Henrique Martins; 3) Corner with Saldanha Marinho street, right side; 4)Left side of the Avenue near the corner with Saldanha Marinho street; 5)Front and side areas of the N. S. da Conceição Church and the 6)Region between the streets Quintino Bocaiuva and Marquês de Santa Cruz. The information reported below, were based on the works of Duarte (2009), Carlos (2017), Souza and 
Oliveira (2016), Mesquita (2019), Corrêa (1969) in line with the results obtained during the field research.

1) Corner with Monsenhor Coutinho Street: Where today is the Maximino Corrêa residential building (exactly on the corner of Eduardo Ribeiro avenue with Monsenhor Coutinho Street) there was once one of the most beautiful buildings of Manaus: the Palacete Miranda Corrêa ${ }^{4}$. The Palacete Miranda Corrêa was bought from a rich Portuguese merchant, it had an architectural style inspired in the mansions of the French monarchy, it had two floors, a high basement and a mansard attic besides a rich furniture imported from Europe. For its beauty and style, it formed a harmonious architectural ensemble with the building of the State Health Department demolished in 1969 and the Ideal Club ${ }^{5}$ building as well as the Antônio Bittencourt square. In 1971, the Palacete was demolished and gave place to a residential ${ }^{6}$ building that stands out negatively in the landscape causing a visual pollution in the area. Below in figure 5, comparative images of the place:

Figure 5 - Corner with Monsenhor Coutinho Street undated (left) and in 2019 (right)

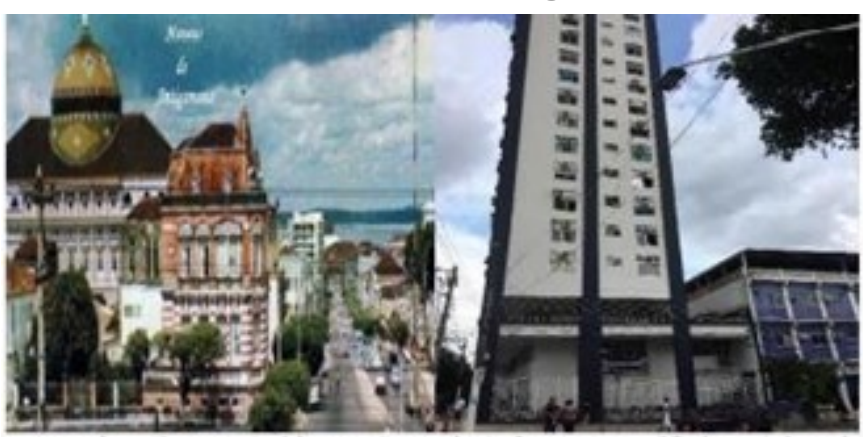

Source: <http://manausdeantigamente.com.br> (2019)

2) Space between the streets 24 de Maio and Henrique Martins: This space of the Avenue, located exactly between the streets 24 de Maio and Henrique Martins, presented, on both sides of the road, a beautiful houses, mostly in eclectic style and with some specimens of very simple appearance, which housed commercial houses, warehouses, newspapers, banks, bars, among others. With the passing of time, the implementation of the Manaus Free Trade Zone economic model (1967) and the inertia of the competent bodies, many historic buildings were demolished and gave way to shops and residential and commercial buildings. However, the few old buildings that still remain in this area are mostly taken over by advertising, electricity wires

\footnotetext{
${ }^{4}$ Which belonged to the Miranda Corrêa family. Originally from Pará, this family made their fortune at the beginning of the 20th century, during the heyday of the rubber trade in the Amazon.

${ }^{5}$ Today it houses the Gebes Medeiros Theatre.

${ }^{6}$ And that, ironically, is named after one of the descendants of the family that once owned the beautiful palace, Maximino Corrêa
}

and telephone cables, with their structure, especially in their facades, uncharacterised by paintings and other interventions that did not take into account their original appearance. Despite this, there are still historic buildings on this part of the street that remain partially preserved and with their facades little altered ${ }^{7}$, the contrast between the old buildings and the contemporary buildings accentuates the break in the continuity of the architectural ensemble in this area, as can be seen in the images below (Figure 6).

Figure 6 - Stretch of the Avenue between Ruas 24 de Maio and Henrique Martins in the 1930s (left) and in 2019 (right)

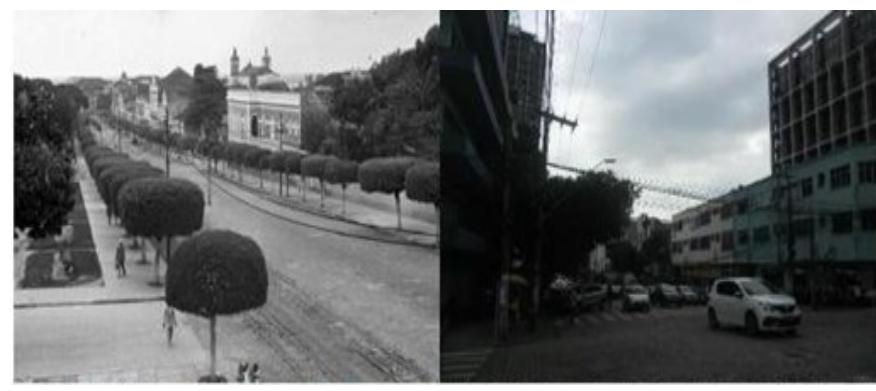

Source: <http://manausdeantigamente.com.br> (2019)

3) Corner with Saldanha Marinho street, right side: On this corner, there was one of the most famous movie theater of Manaus: the Odeon movie theater ${ }^{8}$, which was opened by the company Moreira, Lages \& Cia. on February 21, 1913. Its rooms were luxurious, with upholstered furniture, drinking fountains and bomboniere, its capacity was 380 seats and its architectural style followed the trends of most buildings erected in the early twentieth century, however, it has undergone several reforms that significantly changed its architectural fea-

Figure 7 - Corner with Saldanha Marinho street, right side in 1973 (left) and in 2019 (right)

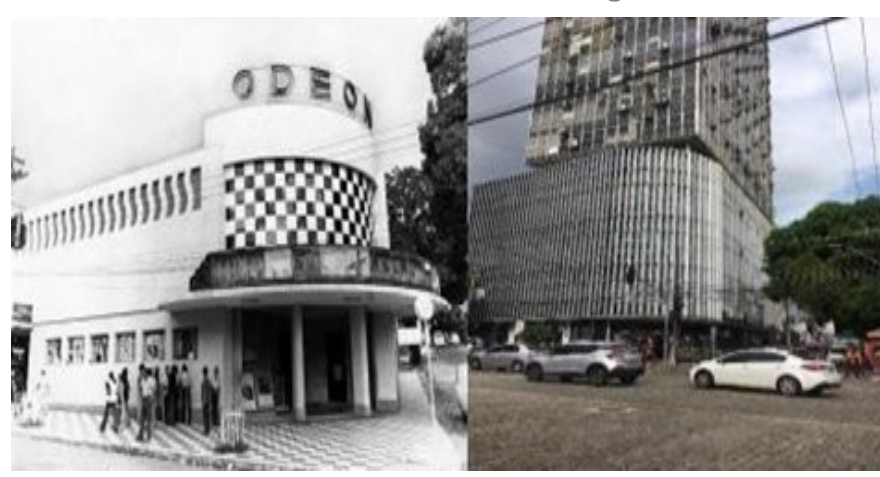

Source: Duarte \& Durango (2009); Author photo (2019).

${ }^{7}$ For example, the building occupied by a Marisa shop and the building that housed for a long time the Carrefour supermarket (corner of Saldanha Marinho street)

${ }^{8}$ The first film to be shown at the Odeon was The Sons of the General and the last was The Stain of the Past 
tures. The cinema closed its activities on June 22nd, 1973, after 60 years of operation, being sold and then demolished to make way for the building Manaus Shopping Center, with twenty floors and active to this day (Figure 7).

4) Left side of the Avenue near the corner with Saldanha Marinho street: On the left side of Eduardo Ribeiro avenue, near Saldanha Marinho street, there was another famous movie theater in town: the Cine Avenida, which opened in 28 November 1909, going through several reformulations and different places, being its last headquarters almost in front of the Odeon movie theater, place that today belongs to the Benchimol group. With capacity for 642 people ${ }^{9}$ its facade was striking even after some reforms, it kept its peculiar characteristics, although its architectural style is considered simple. On July 2,1973, it closed its activities and the building was sold to the Benchimol Group, which reformed it and transformed it into an electronics shop operating until today, below comparative images of the place (Figure 8).

Figure 8 - Cine Avenida in the 1930s (left) and landscape of the site in 2019 (right)

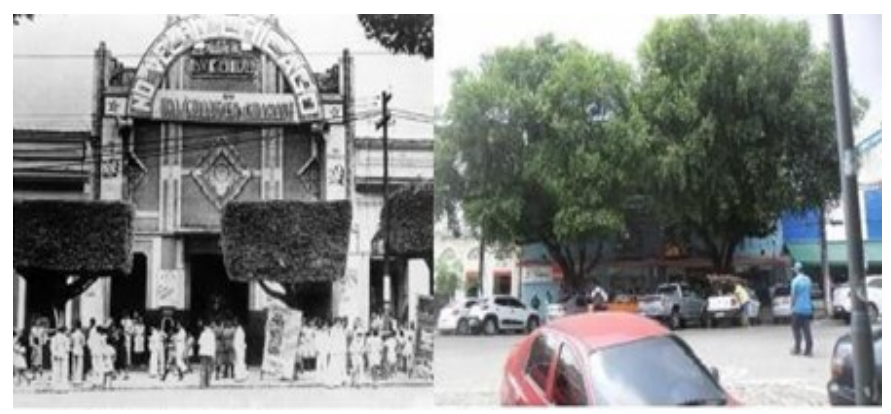

Source: Duarte \& Durango (2009); Author photo (2019).

5) Front and side areas of the N. S. da Conceição Church: This area was one of the most beautiful and cozy of Manaus with wooded areas distributed in the surroundings of the Matriz church, monuments, urban equipment (benches, bridges, bandstands, fountains, pavilions, ramps, among others until the mid-1970s, when three of the four gardens that made up this street were removed and transformed into paved roads and bus terminals. The area occupied by the Matriz Gardens was also rich in trees and ornamentation, besides having sheltered an Aviary and the Municipal Garden, however, all this territory that made up the Matriz complex (Figure 9) suffered several interventions over the years, ending up mischaracterizing the place almost completely. Nowadays, only 15 de Novembro square and the Matriz side gardens still resist, even without showing some of their original characteristics,

${ }^{9}$ It showed Tarzan, Bang-Bang and Roman films, and had a mezzanine from which the public could watch the films from above now with new urban equipment installed and surrounded by kiosks. (left side) and several commercial establishments (front area and right side).

Figure 9 - Surroundings of the Matriz Church undated (left) and in 2019 (right)

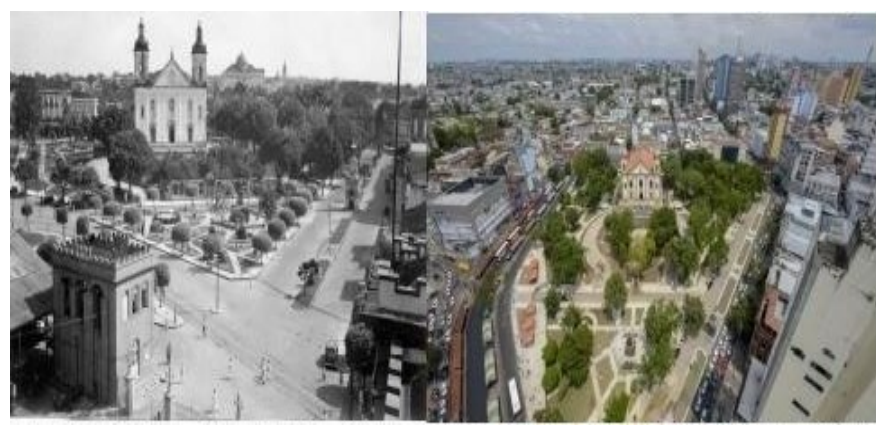

Source: Monteiro \& Mário Ypiranga (1998); <http:// viajabrasil.com.br> (2019).

6) Region between the streets Quintino Bocaiuva and Marquês de Santa Cruz: This space, like much of Eduardo Ribeiro avenue, once consisted of a beautiful houses that housed shops, cafes and boutiques, as well as the Post Office and Telegraph Agency. However, with the disorderly growth of the city, the commercial and real estate expansion caused by the advent of the Manaus Free Trade Zone (late 1960s and mid-1980s), the landscape of this place was changed, some buildings were demolished and gave way to large buildings with several floors, such as the Federal Revenue building. Other buildings are in a state of abandonment, graffiti and damaged structure (the former Post and Telegraph Agency, for example), besides those that today house shops and commercial departments of various segments that had their facades covered by advertising boards and awnings and were painted without any concern with their original appearance. Below (Figure 10) are exposed comparative images of this space as a way to illustrate the transformation and decharacterization.

Figure 10 - Region between Quintino Bocaiuva and Marquês de Santa Cruz streets. On the left without date and on the right in 2019

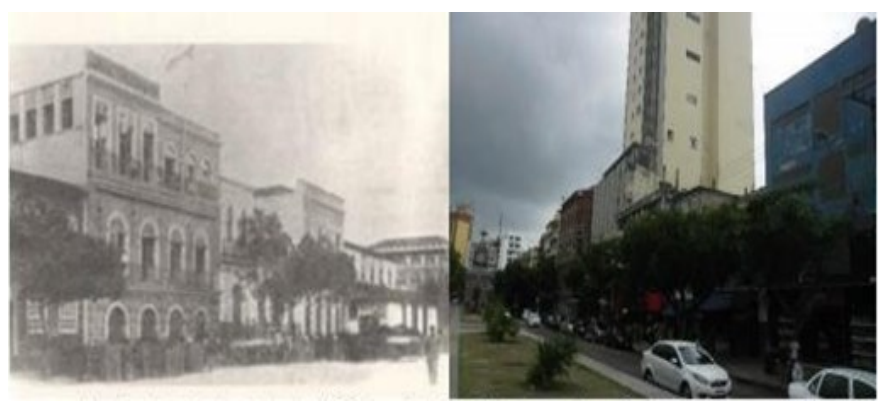

Source: Andrade \& Moacir (1984); Author photo (2019). 
As a complementary way to the comparison of the spaces presented above, it should be exposed, also, an overview of the Eduardo Ribeiro avenue in its before and after, since the landscape of the road in all its length was quite changed, it is possible to verify, by comparing the "before and after" of the Avenue, that the urban spaces are built according to the moment the local society lives, this means that "[...], the cities are being formed and transformed to meet the goals of its multiple builders. To function according to the competing parameters that characterize a particular time", elucidate Melo and Vogel (1984, p. 6). Eduardo Ribeiro avenue is characterized as a landscape that was built to meet the interests of the dominant social group at that time (rubber boom period), its main interventions happened during the implementation of the economic model of the Manaus Free Trade Zone and also end up showing this adaptable character of the urban space according to the period experienced, in which historic buildings and urban equipment are replaced by modern facilities that represent the present time. Thus, below (Figure 11) are displayed comparative images of the Avenue as an illustration of what was explained above.

Figure 11 - Eduardo Ribeiro Avenue in 1897 (left) and in 2019 (right)

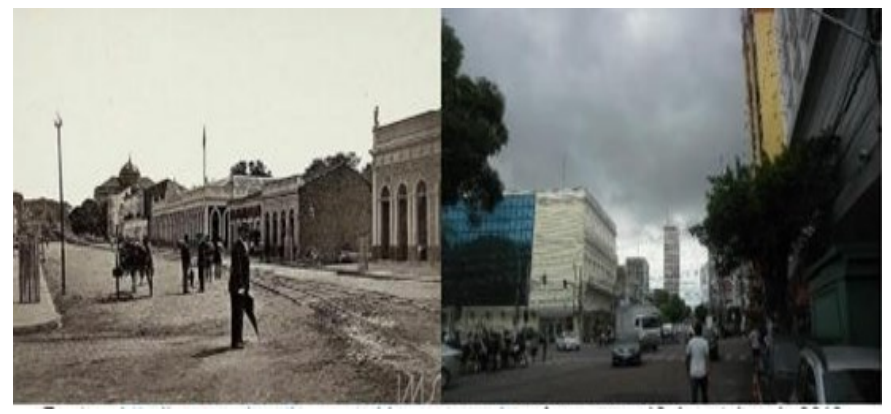

Source: <http://manausdeantigamente.com.br> (2019)

The Eduardo Ribeiro avenue and its historic buildings are demonstrably part of the historical and cultural heritage of Manaus, being in the legal perimeter of conservation at the municipal, state and federal levels, therefore, it is understood that this street and its surroundings are important for greater historical and socio -cultural understanding of the city besides representing a space of tourist attraction. Thus, the development of a tourist route that intends to tell the story of the road, and therefore the history of Manaus, using instruments that enhance the experience of the participants and raise awareness about the importance of preserving heritage assets, can represent a tool for valuing the historicity and local culture, as to boost tourism activity in the locality.

\section{Applying scientific knowledge to the tourism mar- ket}

The city of Manaus needs to rescue the past and present events so that there is a better appreciation and understanding of the richness of their cultural heritage in line with the places that contemplate the perspective of the old and new. It is known that the development of tourist routes can work as a dynamizer of the tourist destination and can promote greater integration of society in the development of local tourism, especially in urban areas, since "[...], offer social, cultural, physical and aesthetic scenarios on which the tourist activity can be developed", highlight Hayllar, Griffin, Edwards Aldrigui, (2011, p.3). Given the above, a script that brings an interpretive look at the evolution of the urban landscape of Eduardo Ribeiro avenue and its surroundings, will bring light to a landscape and tourist aspect not yet evidenced in the capital manauara, which would enable a gain in the quality of tourist and educational experience of residents and visitors. This routing proposal is based on the main evolutionary, historical, cultural, urban and social aspects of the manauara and Amazonas society.

The idea is to unite the historicity already exposed in this article and transform the Eduardo Ribeiro Avenue in a tourist route (Figure 12) that can be performed in guided groups with a maximum of 8 people, plus a tour guide and a support person or individually using the informative materials about the space in question and following the available signs and panels already existing in the street. The format designed for the route aims to provide a quality tourist service that meets the most important precepts of heritage interpretation: to be accessible to all, to respect the environment in which the heritage is inserted and to protect the heritage and itself.

Figure 12 - Map of the Tourist Roadmap of Eduardo Ribeiro Avenue

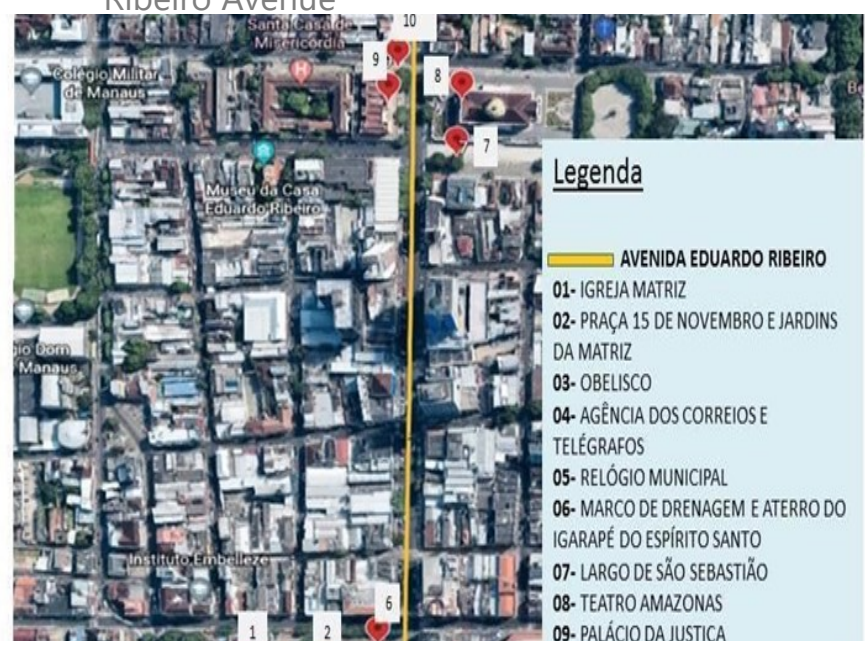

Source: Prepared by Tássia Milena Pires de Souza and Yara Araújo Magabi. 
This division aims to organize the route and better understand the Avenue and its buildings as well as the surrounding landscape. For this definition, the days and times of visitation to the buildings open to the public in the period 2018/2019, the geographical arrangement of the attractions that make up the route and the safety conditions in the area were considered. Table 1 below summarizes the main technical aspects for the preparation of the aforementioned roadmap, based on Bahl (2004):

Table 1 - Factsheet of the Eduardo Ribeiro Avenue Roadmap

\begin{tabular}{l|l}
\hline EDUARDO & RIBEIRO AVENUE ROADMAP 2020/2021 \\
\hline ITEM & DETAIL / SPECIFICS \\
\hline $\begin{array}{l}\text { 1. Objec- } \\
\text { tives }\end{array}$ & $\begin{array}{l}\text { Cultural Tourism and Heritage } \\
\text { Education/Interpretation }\end{array}$ \\
\hline 2. Target- & Maximum of 8 people in a group orindividu-
\end{tabular}

ing ally. Adults, young people and children (from 5 years old). Restrictions apply for those with special needs due to the lack of accessibility to the pavements and certain attractions

\begin{tabular}{ll|l}
\hline 3. Title & $\begin{array}{l}\text { Interpreting Manauara's heritage: a new } \\
\text { look at Eduardo Ribeiro avenue }\end{array}$ \\
\hline 4. Attrac- & Total of 15 of which: The history of the Ave-
\end{tabular}
tions

5. Days and Hours nue (pre-building + construction + evolution + present time); N. S. da Conceição Church (located on the left); 15 de Novembro Square and Gardens (locatedon the left); Obelisk (located in the central garden); Post and Telegraph Agency (located on the right); Municipal Clock (located in the central garden); Landmark of the drainage and embankment of the Espírito Santo creek (located underground on the left side of the Matriz Church); São Sebastião Square (located on the right); Amazonas Theatre (located on the right); Palace of Justice (located on the left); Landmark with the original tramway tracks (located on the left): Former Ideal Clube building/ Gebes Medeiros Theatre (located on the left); Antônio Bittencourt Congress Square (located in the centre); Eduardo Ribeiro's plaque and bust (located on Congress Square) and IEA building (located in the centre, up the avenue)

The Avenue may be visited every day during the day. However, visits to the Church, the theatres and the Palace of Justice will take place according to the schedules and programmes made available by their respective administrations. The days from Tuesday to Sunday are pre- established for the realization of the route, with adjustments in the programming of Sundays, due to the Handicraft Fair thattakes place on the way

\begin{tabular}{|c|c|}
\hline $\begin{array}{l}\text { 6. Visitor } \\
\text { Fees }\end{array}$ & $\begin{array}{l}\text { Access to the listed buildings and sites is } \\
\text { free, except for the Amazonas Theatre, } \\
\text { where admission costs } R \$ 20.00 \text { (full price) } \\
\text { and } R \$ 10.00 \text { (half price) for visitors who } \\
\text { are not citizens of Amazonas. }\end{array}$ \\
\hline $\begin{array}{l}7 . \quad \text { Itiner- } \\
\text { ary }\end{array}$ & $\begin{array}{l}\text { Approximately } 961 \text { metres of walking. The } \\
\text { starting point is the Igreja Matriz, which is } \\
\text { part of Ensemble A (whose visitation takes } \\
\text { approximately } 120 \text { minutes). From Ensem- } \\
\text { ble A to Ensemble B (approximately } 459 \\
\text { metres away), the walk takes approximately } \\
10 \text { minutes. In Group B, the visitation } \\
\text { takes approximately } 120 \text { minutes. } \\
\text { From Conjunto B to Conjunto C } \\
\text { (approx. } 180 \text { metres away), the walk takes } \\
\text { about } 5 \text { minutes. In Ensemble C, the tour } \\
\text { lasts approximately } 60 \text { minutes. The end } \\
\text { point is the IEA building. The direction to } \\
\text { be followed on this route is Center- Base- } \\
\text { ment, obeying the direction of the flow of } \\
\text { automobiles on most of the Avenue. }\end{array}$ \\
\hline $\begin{array}{l}\text { 8. } \\
\text { ber } \\
\text { stops }\end{array}$ & $\begin{array}{l}3 \text { stops to get acquainted with the Avenue } \\
\text { and visit the main buildings (Sets } \mathbf{A} \text { to } \mathbf{C} \text { ). A } \\
\text { time will be set aside for access to re- } \\
\text { strooms and consumption of water and/or } \\
\text { snacks (technical stop) with an average du- } \\
\text { ration of } 15 \text { to } 20 \text { minutes within the itiner- } \\
\text { ary. The Palácio da Justiça Cultural Centre } \\
\text { has an adequate structure for the technical } \\
\text { stop. }\end{array}$ \\
\hline $\begin{array}{l}9 . \\
\text { Transport }\end{array}$ & $\begin{array}{l}\text { To get to the Avenue you can use cars } \\
\text { (motorbikes, buses or minibuses), even } \\
\text { walking (if the accommodation or residence } \\
\text { is close to the avenue). To complete the } \\
\text { route, the type of tour should be on foot, } \\
\text { since the Avenue does not follow a single } \\
\text { hand (direction of the flow of automobiles) } \\
\text { along its entire length, presenting an invert- } \\
\text { ed hand at the corner with Sete de Setem- } \\
\text { bro Avenue (this inversion is located in the } \\
\text { section of Set A - around the Matriz } \\
\text { Church), referring to the circulation of vehi- } \\
\text { cles. }\end{array}$ \\
\hline 10. Guide & $\begin{array}{l}\text { The route may be made with the presence } \\
\text { of a guide (and a support person, who will } \\
\text { help coordinate the group) or not, requiring } \\
\text { only the use of informative materials about } \\
\text { the area in question and the monitoring of } \\
\text { the signs and panels available. }\end{array}$ \\
\hline $\begin{array}{l}\text { 11. Dura- } \\
\text { tion }\end{array}$ & Approximately 4 to 5 hours. \\
\hline $\begin{array}{l}\text { 12. Sched- } \\
\text { ule }\end{array}$ & 09h00min until 14h00min \\
\hline 13. Local & $\begin{array}{l}\text { Output: Point A (Matrix Set); } \\
\text { Arrival: Point C (Conjunto da Praça do } \\
\text { Congresso). }\end{array}$ \\
\hline $\begin{array}{l}14 . \\
\text { Product/ } \\
\text { Routing }\end{array}$ & $\begin{array}{l}\text { Map of the route already presented above } \\
\text { (figure 12). }\end{array}$ \\
\hline
\end{tabular}




\begin{tabular}{l|l}
\hline 15. Price & $\begin{array}{l}\text { Visiting the buildings and squares is free, } \\
\text { except for the Amazonas teatre, where a fee } \\
\text { of } \mathrm{R} \$ 20.00 \text { (full) and } \mathrm{R} \$ 10.00 \text { (half) is } \\
\text { charged for visitors who are not citizens of } \\
\text { Amazonas. }\end{array}$ \\
\hline $\begin{array}{l}\text { 16. Evalu- } \\
\text { ation }\end{array}$ & $\begin{array}{l}\text { A form will be made available to partici- } \\
\text { pants for evaluation after the effective im- } \\
\text { plementation of this proposal. }\end{array}$ \\
\hline
\end{tabular}

Source: Produced by the authors.

Thus, the applicability of this scientific research is based on the understanding of Gastal (2006) when he states that the interpretation of cultural heritage from the tourist routing is an important action that recognizes the magnitude of this, valuing and preserving the memory of the place, generating belonging and spatial identity through the landscape, because in the localities are "the marks of the place built in time" (p.101, 2006). The theme of the Eduardo Ribeiro avenue route is focused on cultural tourism and seeks to highlight the different moments of the history of Manaus, the spatial evolution of the Avenue and the socio-cultural formation of the Manaus society, making use of the means and techniques of heritage interpretation as tools to enrich the tourist experience and enhance the local heritage.

In order to direct this new perspective of the look, Murta and Goodey (2002) mention that the cultural enhancement is a process of adding value to the visitor experience, with the provision of information and representations that exalt the history and cultural and environmental characteristics of a place. Therefore, this suggestion is based on the understanding that Manaus needs new and differentiated products and tourist services so that tourism in the capital can prosper. The route of Eduardo Ribeiro avenue can become another option for travel agencies, for the competent bodies and for the local tourist trade. In the academic field, the merit of this research lies in the theoretical contribution of aligning the themes tourism and heritage interpretation that together broaden the knowledge about an object that lacks further research.

\section{CONCLUDING REMARKS}

This study compiled historical information about the origins of Eduardo Ribeiro avenue as well as analyzed its relevance to the identity formation and cultural heritage of the Manaus society, determining how these aspects of the place can be analyzed in the context of heritage interpretation through a suggestion for a tourist route focused specifically on the Avenue. Seeking also to uncover facts and aspects relating to Eduardo Ribeiro avenue still unknown to much of the pop- ulation of Manaus, these elements are also part of the origins of the capital of Amazonas and the society that resides here.

The research revealed that Eduardo Ribeiro Avenue appears during a period of significant transformations in Manaus. It was possible to verify that the avenue was planned to be an exemplar of the great European avenues (these are wide avenues, on which the most important and imposing buildings of the city are located), this planning, however, did not take into consideration the physical particularities of the city, nor the peculiar characteristics of its inhabitants.

As for the practical applications of the research results, it is recommended the implementation of the tourist route of Eduardo Ribeiro avenue, which can be operated both by non-profit organizations, companies in the tourism area as well as public agencies to strengthen the differentials of the tourist destination Manaus. However, investments are required in training of professionals, in the preparation of materials used during the implementation of the route, in the installation of equipment at strategic points of the road in question and structural interventions aimed at solving problems related to accessibility and public safety in some spaces of the Avenue.

The results rescue part of the local memory and present itself as a complementary instrument for the valorisation of the Avenue and, consequently, the city's history. Providing to the Manaus tourism, a new route option focused on the quality of the tourist experience based on the heritage interpretation representing the diversification of tourist services offered. In addition, this study brought the possibility of expanding the look to other streets and spaces of the city, such as Joaquim Nabuco avenue, also located in the Historic Centre of Manaus and which presents historical, urban, landscape and social aspects of significant relevance to the capital.

\section{REFERENCES}

Andrade, M. (1984). Manaus: ruas, fachadas e varandas. Manaus, Humberto Calderaro.

Anjos, J. G. dos, \& Pereira, J. (2011). Manáos... Uma nobre sedução. Organização de José Geraldo dos Anjos e Jaime Pereira/ Manaus: Edições Muiraquitã.

Aranha, R.de.C., \& Guerra, A. J. T. (2014). Geografia aplicada ao turismo. São Paulo: Oficina Textos.

Bahl, M. (2004). Viagens e roteiros turísticos. Curitiba: Protexto.

Barretto, M. (2007). Cultura e turismo: Discussões contemporâneas. Campinas, SP: Papirus. 
Batista, S.P. (2013). Injustiça Sociambiental: O Caso PROSAMIM/ Selma Paula Batista; orientador Wagner Costa Ribeiro. São Paulo.

Beni, M.C. (2007). Análise estrutural do turismo. $12^{\circ}$ ed. rev. e atuali.- São Paulo: Editora Senac São Paulo.

Boullón, R.C. (2002). Planejamento do espaço turístico. Bauru, SP: EDUSC.

Cardozo, P.F. (2012). A interpretação do patrimônio histórico romano na cidade de Mainz, Renância Palatinado (Alemanha). Pasos - Revista de turismo y patrimonio cultural, Universidade e La Laguna, Santa Cruz de Tenerife. v. 10, n. 1.

Carlos, A.B. (2017). A Manaus que eu vi e vivi: histórias e estórias. Manaus: Reggo.

Choay, F. (2001). A alegoria do patrimônio. São Paulo: Estação Liberdade/ Ed. Unesp.

Corrêa, L. M. (1969). Manaus: Roteiro Histórico e Sentimental da Cidade do Rio Negro. Rio de Janeiro: Artenova.

Dencker, A. F. M. (1998). Métodos e técnicas de pesquisa em turismo. São Paulo: Futura.

Dias, E.M. (2007). A ilusão do fausto: Manaus, 18901920. Manaus: Valer.

Duarte, D.M. (2009). Manaus entre o passado e o pre-

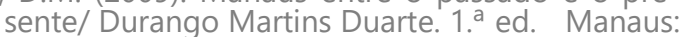
Ed. Mídia Ponto Comm.

Garcia, E. (2014). Manaus, referências da História. 3 ed. ver. Manaus: Editora Norma.

Gastal, S. (2006). Alegorias urbanas: o passado como subterfúgio: tempo, espaço e visualidade na pós -modernidade. Campinas, SP: Papirus.

Guimarães, M.R.C. (2012). A paisagem urbana como diferencial no turismo em Manaus: Uma análise da Avenida Sete de Setembro. Balneário Camboriú: UNIVALI.

Guimarães, M.R.C., Maia, K.C.R., Oliveira, S.d.S., \& TricáriCo, L.T. (2020). Interpretação do patrimônio cultural por meio da roteirização turística da Avenida 7 de Setembro, Manaus, AM. Interações (Campo Grande), 21(3), 479-497. Epub October 26, $2020 . \quad$ https://doi.org/10.20435/ inter.v21i3.2364.

Guimarães, M.R.C., \& Pereira, R.M.F.d.A. (2012). Avenida Sete de Setembro: o retrato de um passado presente e o seu legado para o turismo em Manaus-Amazonas. In: Seminário da Associação Nacional de Pesquisa e Pós-graduação em Turismo, 9., 2012, São Paulo.Anais [...]. São Paulo: Anptur.

Hall, S. (2001). A identidade cultural na pósmodernidade. 10. ed. Rio de Janeiro: DP\&A

Hayllar, B., Griffin, T., Edwards, D., \& Aldrigui, M. (2011). Turismo em cidades: espaços urbanos, lugares turísticos. Rio de Janeiro: Elsevier.
Iphan. Instituto do Patrimônio Histórico e Artístico Nacional. Disponível em: http://portal.iphan.gov.br/ Acesso em 20.out.2019.

Lohmann, G., \& Netto, A.P. (2008). Teoria do turismo: conceitos, modelos e sistemas. São Paulo: Aleph, 2008.

Mansour, P. M. (2017). Avenida Eduardo Ribeiro, principal via do centro de Manaus já foi braço do Rio Negro conheça história. Disponível em: http:// g1.globo.com/am/amazonas/noticia/ . Manaus 24/10/2017. Acesso em 20.out. 2018.

Melo, M. A. da. S., \& Vogel, A. (1984). Sistemas Construídos e Memória Social: Uma Arqueologia Urbana? In: Revista de Arqueologia. Belém: Museu Paraense Emílio Goeldi, v. 2, n. 2, jul/dez. pp. 46-50.

Mesquita, O. M. de. (2005). La belle vitrine: O mito do progresso na refundação da cidade de Manaus (1890-1900). 439 f. Tese (Doutorado em História) - Curso de Pós-Graduação em História, Universidade Federal Fluminense, Niterói.

Mesquita, O.M.de. (2019). Manaus: história e arquitetura (1669-1915) 4 ed revisada e ampliada. Oton Moreira de Mesquita. -Manaus: Editora Valer.

Monteiro, M.Y. (1998). Roteiro Histórico de Manaus. Manaus: Editora da Universidade do Amazonas $2 \mathrm{v}$.

Murta, S.M. \& Albano, C. (2002). Interpretar o patrimônio: um exercício do olhar. Belo Horizonte: Ed. UFMG: Território Brasilis.

Murta, S.M., \& Goodey, B. (2002). Interpretação do patrimônio para visitantes: um guadro conceitual. In: Murta, S. M.; Albano, C (Ed./Org.). Interpretar o patrimônio: um exercício do olhar. Belo Horizonte: Ed. UFMG: Território Brasilis.

Oliveira, S. da S., Guimarães, M.R.C., Prata, E.L., \& Silva, I.F.da. (2019). Analysis of the promotion of the historic center of Manaus in the city's printed tourist guides. Applied Tourism, 4 (3), 32-46.

Pupo, G.H. (2011). La interpretación del patrimonio cultural para la gestión turística. Retos Turísticos Camagüey, Cuba, v. 10, n. 1-2, p. 21-7, fev./set.

Santos, M. (1988). Metamorfoses do espaço habitado fundamentos teórico e metodológico da geografia. São Paulo: Hucitec.

Souza, A.C. (2005). A cidade de Manaus no dizer dos viajantes. In: ANPUH- XXIII Simpósio Nacional de História, Londrina, p. 1-7.

Souza, L.C.de., \& Oliveira, J.A.de. (2016). Do caminho de canoa às escadas dos arranha-céus: Avenida Eduardo Ribeiro, Manaus, Amazonas. In: Geosaberes, Fortaleza, v.6, número especial (3), p. 530540, Fevereiro.

Vieira, L.L. \& Oliveira, I.J.de. (2012). Turismo, espaco e paisagem: Uma abordagem geográfica da escoha de destinos turísticos na era digital. Universidade Anhambi Morumbi - São Paulo.

Xavier, H. (2007). A percepção geográfica do turismo. Aleph. 